\title{
Mapping of the current land use in part of the Irrigated Perimeter Nilo Coelho, Petrolina-PE, Brazil
}

\author{
Ricardo Rivelino Dantas Ramos, Júlio César Ferreira de Melo Júnior*
}

Federal University of San Francisco Valley, Petrolina, Brazil *Corresponding author, e-mail: julio.melo@univasf.edu.br

\begin{abstract}
The objective of this study was to quantify and spatialize the agricultural composition and current land use in part of the Irrigation perimeter Nilo Coelho from the Landsat 8 satellite digital image classification. At first we performed the unsupervised classification image related to January 2014 , identifying the separability within natural vegetation, water bodies, agricultural crops and anthropized areas. Then the supervised classification Maxver model was performed where it was observed that the fruit classes "Grape" (5.41\%) "Acerola" (3.75\%), "Coconut" (6.14\%) "Guava" (6.17\%), "Banana" $(2.29 \%)$ and "Mango" $(8.18 \%)$ showed dominance in the study area. These classes stood out in terms of yield in the area, pointing out that in that expansion which occurs in an area with agricultural crops in the irrigated Nilo Coelho, crops of mango, coco, guava, acerola, banana and grape also grow. In addition, we observed the emergence of new areas with passion fruit crops, melon, watermelon, corn, beans, onions, pumpkin, sweet potatoes, tomatoes, bell peppers, among other crops. Furthermore, we also found the occurrence of pastures containing buffel and elephant grasses, intercropping or not. The estimated overall accuracy was $80.52 \%$, and the mapping defined as very good, with Kappa index equal to 0.7783 . Keywords: fruticulture, image classification, Kappa coefficient, maximum likelihood, remote sensing
\end{abstract}

\section{Introduction}

In the world ranking of fruit production, Brazil stands out in third place, with 40.996 .600 tons produced in 2011 , representing $6,43 \%$ of the harvested fruits in the entire planet (FAO, 2014). Among the poles of national fruticulture, the São Francisco Valley is a region where irrigated fruticulture stands out as the main agribusiness activity.

In the last decades, the JuazeiroPetrolina pole, due to incentive policies and the availability of water for irrigation, became a great fruit producer nucleus, fruits which are commercialized in the internal market and exported for the USA, Europe and Asian Southeast
(Melo Júnior et al., 2015).

With the development of agriculture in the São Francisco Valley, allowed by irrigation, the region went through a socioeconomic transformation of its agrarian space (Araújo \& Silva, 2013). In this manner, it is necessary to obtain knowledge of the area occupation by the crops, as well as stablishing yield estimations. In this context, classification techniques of satellite imagery have aided in the mapping of use and occupation of the soil (Nery et al., 2013).

Therefore, remote sensing presents a relevant role, as a viable alternative for the information extraction on soil usages, covering and surface transformations (Rodrigues et al., 
2014; Ferreira et al., 2010).

For the mapping of the land cover the parametric classification techniques are highlighted: not supervised and supervised (Andrade et al., 2014). The first technique does not require information on features, being examined without the aid of an interpreter (Moreira, 2011). As to the supervised technique, it consists in the previous identification of the classes and collection of field information, which represent the spectral behavior of those about to be mapped. According to Rodrigues et al. (2014) the most utilized algorithm for the performing of this type of classification is the maximum likelihood (Maxver). This algorithm computes the probability of an unknown pixel belong to a determined class in comparison to others (Leite \& Rosa, 2012). Furthermore, Borges \& Silva (2009) highlight the importance of the interpreter in the supervision of the image classification.

The model precision depends on factors such as: terrain complexity, overlap within features and low spatial and spectral resolutions of the sensors (Amaral et al., 2009). This precision is expressed in terms of indexes, which are calculated based on error matrices which describe the concordance between the classified image and the set of reference samples. Among these indexes the Kappa coefficient is highlighted, widely utilized for the trustworthiness evaluation of the classification (Tisot et al., 2007; Silva et al., 2013; Silva Júnior et al., 2013).

With the exposed, this work aimed to quantify and to spatialize the composition of agricultural crops of higher economical relevance: grape, mango, banana, acerola, guava and coconut, among others, in the $\mathrm{Cl}$, C2, N1, N2, N3, N4 and N5 nuclei of the Nilo Coelho irrigation perimeter.

\section{Material and Methods}

The study area is located in the Petrolina - PE municipality, and belongs to the Nilo Coelho Irrigation Perimeter (PINC), more specifically constituted by the producer nuclei C1, C2, N1, N2, N3, N4 e N5, totalizing an area of 18.303,56 ha, inserted under the geographical coordinates $40^{\circ} 23^{\prime} 05,27^{\prime \prime}$ and $40^{\circ} 49^{\prime} 43,76^{\prime \prime}$ of west longitude, and $9^{\circ} 12^{\prime} 37,64^{\prime \prime}$ and $9^{\circ} 26^{\prime} 27,34^{\prime \prime}$ of south latitude (Figure 1). According to the Köppen climatic classification, the region presents a BSwh' type climate, hot semiarid steppe, with the rainy period in the summer (Melo Júnior et al., 2014).

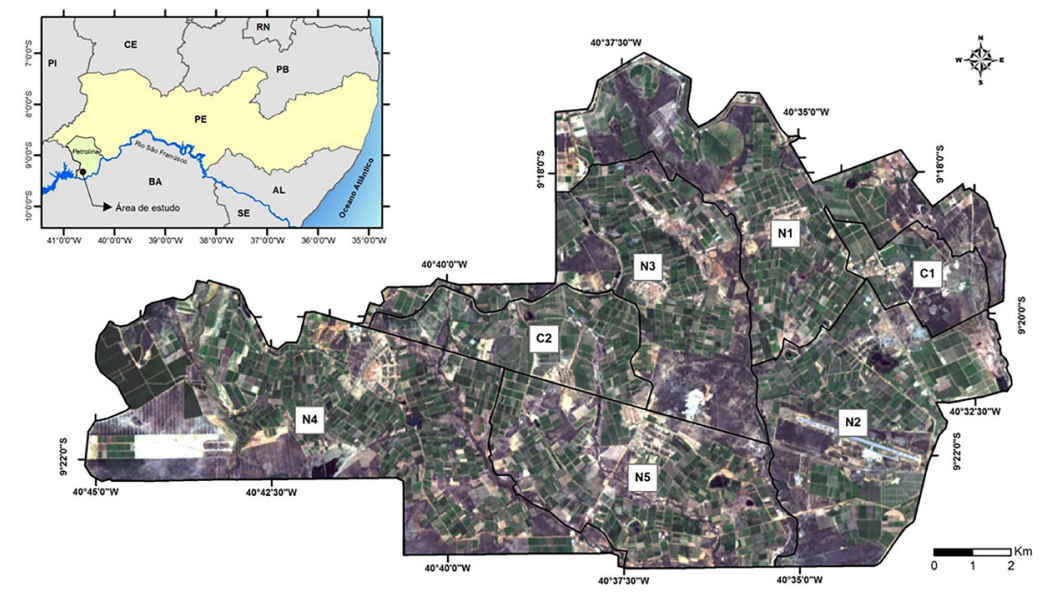

Figure 1. Landsat 8 satellite image representing the study area of the PINC, referent to the C1, C2, N1, N2, N3, N4 and N5 nuclei, in the epoch of January 2014.

The acquisition of the remote sensing image of the studied area was performed from the database of the "National Aeronautics and Space Administration" (NASA) company, referent to the epoch of January 2014. The preprocessing of the digital image of the Landsat 8 satellite involved the stages of radiometric and geometric correction, noise removal and image highlight. The geometric correction was performed based on 20 field control points, tracked with GPS signal receptor, in which the algorithm "Cubic Convolution" was utilized for resampling, with pixels dimensioned $30 \times 30$ $\mathrm{m}$. As cartographic reference, for the maps elaboration, the Universal Transverse Mercator coordinate system (UTM) was utilized, fuse 24 South and Datum SIRGAS 2000. 
The Landsat 8 satellite contains, as imaging system, the instruments "Operational Land Imager" (OLI) and "Thermal Infrared Sensor" (TIRS) (Table 1). The OLI products consist of eight multispectral bands with spatial resolution of $30 \mathrm{~m}$ and a further panchromatic band, which presents spatial resolution of $15 \mathrm{~m}$. The bands which quantify the thermal electromagnetic spectrum (10 and 11) belong to the TIRS instrument, being useful in the providing of information for quantifying the radiation flux density emitted by the targets on the terrestrial surface, which are collected from pixels with $100 \mathrm{~m}$ resolution (NASA, 2013).

Table 1. Specifications of the Landsat 8 satellite imagery system

\begin{tabular}{ccc}
\hline Spectral bands & $\begin{array}{c}\text { Spectral resolution } \\
(\mu \mathrm{m})\end{array}$ & Spatial resolution $(\mathrm{m})$ \\
\hline 1 (Aerosol) & $0,43-0,45$ & 30 \\
2 (Blue) & $0,45-0,51$ & 30 \\
3 (Green) & $0,53-0,59$ & 30 \\
4 (Red) & $0,64-0,67$ & 30 \\
5 (IV* Near) & $0,85-0,88$ & 30 \\
6 (IV* Average) & $1,57-1,65$ & 30 \\
7 (IV* Average) & $2,11-2,29$ & 30 \\
8 (Panchromatic) & $0,50-0,68$ & 15 \\
9 (Cirrus) & $1,36-1,38$ & 30 \\
10 (IV* Thermal) & $10,60-11,19$ & 100 \\
11 (IV* Thermal) & $11,50-12,51$ & 100 \\
\hline${ }_{\text {*infrared }}$ & &
\end{tabular}

After the geometrical correction the spectral irradiance and the reflectance were calculated for the multispectral bands of the Landsat $8 \mathrm{OLI}$ sensor, utilizing the equations 1 and 2 , respectively.

$$
L_{r a d(i)}=L_{i, \min }+\left(\frac{L_{i, \max }-L_{i, \min }}{255}\right) \times G L_{i}
$$

In which,

$\mathrm{L}_{\text {rad(i) }}=$ spectral irradiance in the $\mathrm{i}$ band W. $\mathrm{m}^{-2} \mathrm{sr}^{-1} \mu \mathrm{m}^{-1}$;

$\mathrm{L}_{\mathrm{i}, \max }$ e $\mathrm{L}_{\mathrm{i}, \text { min }}=$ values of maximum and minimal irradiance in the i band, respectively;

$\mathrm{GL}_{\mathrm{i}}=$ gray level in the $\mathrm{i}$ band.

$$
\rho_{0, i}=\frac{\operatorname{Lrad}(i) \times \pi}{\mathrm{E}_{0, \mathrm{i}} \times \cos Z \times \mathrm{d}}
$$

In which,

$\rho_{0, i}=$ spectral reflectance in the $\mathrm{i}$ band;

$\mathrm{d}_{\mathrm{r}}=$ inverse square of the Earth-Sun distance in astronomical unit;

$\mathrm{E}_{0, \mathrm{i}}=$ average value of solar irradiance in the top of the atmosphere in the i band, W.m ${ }^{2} \mathrm{sr}^{-1} \mu^{-1}$ (solar constant for the wavelength $\lambda$, obtained through Planck's law);

$\mathrm{Z}=$ solar Zenith angle of the acquisition instant, rad.

Notwithstanding the performing of the radiometric correction for all bands of the
Landsat 8 sensors, in the imagery classifications the non-utilization of the spectral band referent to the blue wavelength interval $(0,45$ a $0,52 \mu \mathrm{m})$ was opted, whose purpose was to reduce the irradiance diffuse effect of this wavelength band, in the mapping analysis of soil covering.

For the existing identification within the distinct usages and coverings of the soil, either for agricultural practices or for domain areas of conservation of natural vegetation, or even those destined for urban occupations, the nonsupervised classification method was utilized, according to the "Isodata" algorithm, with the purpose of identifying separability intervals within these dominant types of soil coverings in the study area. This stage was almost completely performed through the computational algorithm, with the pixel separation occurring through similar spectral answers. This method is characterized for utilizing the statistical distance of the spectral answer of the land targets in a process defined by three steps: the pixels are interactively classified according to its spectral answers; the criteria are redefined for each class, and the image is reclassified until the identification of patterns, based on the statistical distance of the data (Marinho et al., 2012). The next step was directly performed by the analyst, in which the 
four classes presented by the algorithm were identified and designed as "agricultural crops", "natural vegetation", "exposed soil" and "urban area" (edified).

Utilizing the reflectances obtained from the hyperspectral bands for the strips: 3, 4, 5, 6 e 7 of the Landsat 8 sensors, the image was classified through the pixel supervised method, employing the maximum likelihood algorithm (Maxver) (Tisot et al., 2007; Leite et al., 2011; Antunes et al., 2012; Fernandes et al., 2012; Mello et al., 2012; Prishchepov et al., 2012; Wrublack et al., 2013), considering 11 classes of predefined land features, with an average of ten samplings for feature training, and ten more samplings for the validation of the proposed model in each class.

For the acquisition of the training samplings utilized by the Maxver algorithm and validation of the supervised classification, field expeditions were performed with the aid of a GPS receptor, model Garmin V, synchronized to the GPS TrackMaker $\vee 13.8$ software installed on a portable microcomputer. In this manner the orchards polygonal traces were delimited, as well as the remaining features, totalizing 11 proposed classes: grape crop "Grape", mango crop "Mango", coconut crop "Coconut", banana crop "Banana", guava crop "Guava", acerola crop "Acerola", other crops "Others", areas with exposed soil "Solo_exp", urban areas "Area_urb", areas with natural vegetation "Veg_ nat" and water bodies "Water".

With the training sampling for the feature classes a supervised classification was performed, with the aid of the Erdas Imagine software. Following that, considering the classification model generated by the Maxver algorithm, a result evaluation was performed utilizing the sampled points for the result inference of each class classification.

The precision of the adjusted model and the mapping exactitude were performed with the obtaining of the accuracy percentage of pixels occurrence classified in each class compared to the training and validation samples, respectively. Furthermore, the Kappa index (Tisot et al., 2007; Silva et al., 2013; Silva Júnior et al., 2013) was another utilized statistic to evaluate the mapping trustworthiness, obtained through consideration of the samples which were utilized for the mapping validation. This statistic is a classically utilized indicator for the concordance evaluation between the land truth and the thematic map, obtained after the classification of the remote sensing image (Amaral et al., 2009).

\section{Results and Discussion}

The unsupervised image classification of the study area revealed a good sensibility and efficiency in the identification and separability of the irrigated agricultural areas compared to the anthropized areas, either by edification, paving, or even in agricultural areas which were degraded due to bad soil usage or lying uncultivated. In a general manner, a Kappa index equivalent to 0,71 was found for the mapping; as for the classes of agricultural crop features, exposed soil, urban area and native vegetation, equivalent values correspondent to $0,71,0,72,0,6$ and 0,78 were found for the Kappa index. Mello et al. (2012), evaluating imagery classification methods, verified that in three areas with distinct spectral characteristics the Kappa index, obtained for the classification utilizing the Isodata algorithm, varied between 0,553 to 0,766.

On the other hand, the Isodata algorithm did not distinguish the patterns for the subclasses of agricultural crops, occasioning confusions within domain classes of the acerola, banana, coconut, mango, guava and grape orchards, among others, whose result is presented on Figure 2. According to Moreira (2011), this situation is due to the condition that the unsupervised classifiers aim to execute a training for each pixel, in order to group the classes and minimize the sum of quadratic errors, not distinguishing information within features which present subtle spectral differences.

Through Figure 3 it is possible to observe that the supervised classification was, in fact, the best employed method for separating the classes which presented subtle spectral differences. The results of the supervised classification with the application of the Maxver algorithm presented a higher sensibility in separating the subclasses which constitute the agricultural crops, besides offering a higher exactitude in the domain patters within different orchard types. 


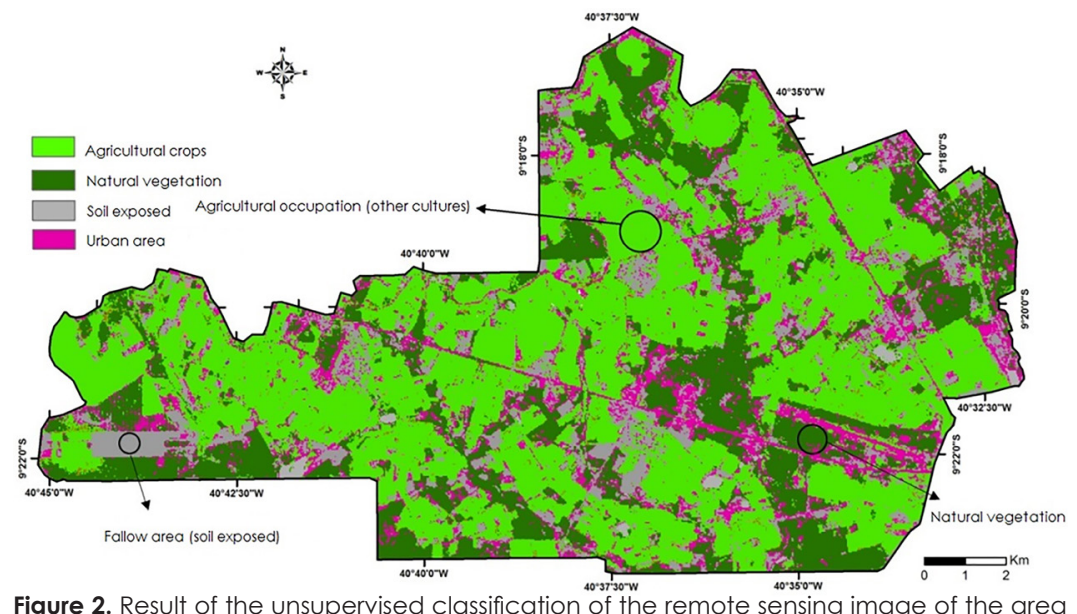

Figure 2. Result of the unsupervised classification of the remote sensing image of the area belonging to the PINC.

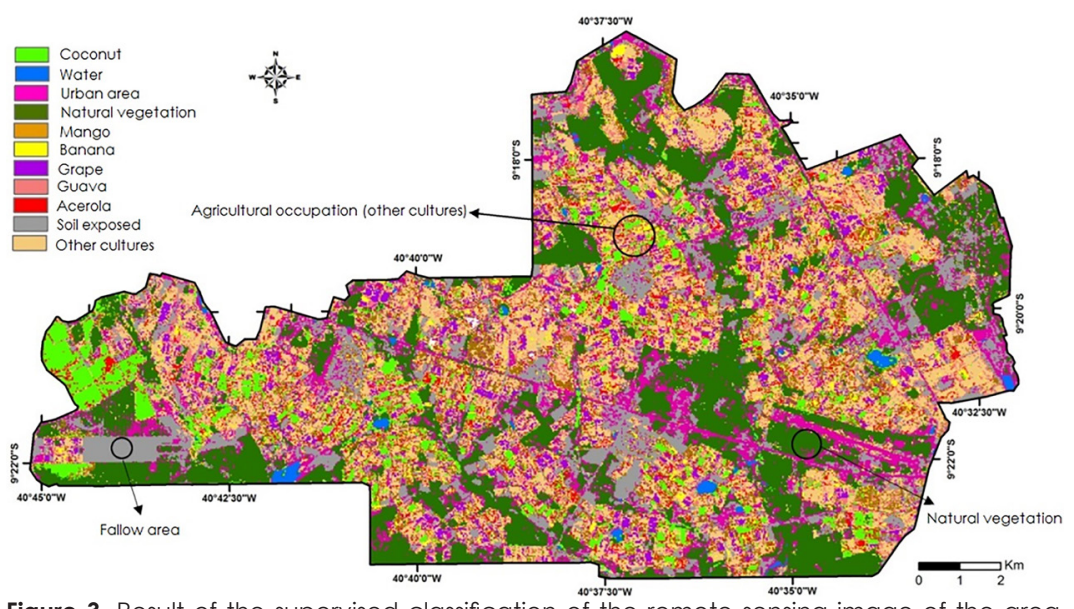

Figure 3. Result of the supervised classification of the remote sensing image of the area belonging to the PINC.

Amaral et al. (2009), evaluating a vegetative surface covered by native forest, concluded that the utilization of the supervised classification method applied to the CBERS, IRS and Quickbird satellite images, was only effective to separate the initial stage of secondary succession from the average and advanced stages. Ferreira et al. (2010), comparing image classifiers, verified that the Maxver algorithm was able to effectively separate classes with lower spectral variability, such as water, shadow, cloud, dense vegetation and dense urban area, and very ineffectively the classes with higher spectral variability, such as wide urban area and altered vegetation. Tisot et al. (2007) inform that the Maxver algorithm was the most efficient to classify areas with subtle spectral differences, when utilized along with hyperspectral sensing images.

The model precision and the mapping exactitude are presented in Table 2, where the determined information for each class of usage and covering of the soil which were identified in the supervised classification are available. The presented results evidence that the higher the number of units for training, the higher the model precision originated through the classification of the digital image, as well as the mapping exactitude, being relevant the terrain complexity and the spatial and spectral resolution of the utilized sensor. The values of $80,52 \%$ and $80,91 \%$ were obtained for the model precision and the mapping exactitude, respectively. Andrade et al. (2014), utilizing the supervised classification method applied to the digital image of the QuickBird satellite, aside from TOPODATA data, obtained for the mapping result an exactitude of $66 \%$. Ferreira et al. (2010) obtained a general mapping accuracy varying from 69 to $77 \%$ for the image classifications utilizing the Maxver algorithm. Fernandes et al. (2012), classifying images of the TM/Landsat-5 sensor obtained a mapping global exactitude of $83,3 \%$. 
Table 2. Precision of the proposed model and mapping accuracy obtained for the area belonging to the PINC, originated through supervised classification of the Landsat 8 satellite image.

\begin{tabular}{|c|c|c|c|c|c|}
\hline Classes' & T.R. ${ }^{2}$ & N.G.T. ${ }^{3}$ & N.H. ${ }^{4}$ & M.P. ${ }^{5}(\%)$ & M.A. ${ }^{6}(\%)$ \\
\hline Acerola & 8 & 10 & 5 & 62,50 & 50 \\
\hline Water & 10 & 10 & 10 & 100,00 & 100 \\
\hline Area_Urb & 11 & 10 & 10 & 90,91 & 100 \\
\hline Banana & 9 & 10 & 7 & 77,78 & 70 \\
\hline Coconut & 12 & 10 & 10 & 83,33 & 100 \\
\hline Guava & 11 & 10 & 7 & 63,64 & 70 \\
\hline Mango & 12 & 10 & 9 & 75,00 & 90 \\
\hline Others & 7 & 10 & 5 & 71,43 & 50 \\
\hline Soil_Exp & 9 & 10 & 7 & 77,78 & 70 \\
\hline Grape & 12 & 10 & 10 & 83,33 & 100 \\
\hline Veg_Nat & 9 & 10 & 9 & 100,00 & 90 \\
\hline
\end{tabular}

The results found for the Kappa statistic are presented in Table 3. For each class of use and covering of the soil, the statistic values were qualitatively classified, based on the proposal utilized by Amaral et al. (2009).

Table 3. Kappa statistic and mapping quality classification, obtained through supervised classification of the remote sensing image, for the area belonging to the PINC.

\begin{tabular}{ccc}
\hline Classes' $^{\prime}$ & Kappa $^{2}$ & QM $^{3}$ \\
\hline Acerola & 0,583 & Good \\
Water & 0,937 & Excellent \\
Area_Urb & 0,881 & Excellent \\
Banana & 0,760 & Very Good \\
Coconut & 0,809 & Excellent \\
Guava & 0,605 & Good \\
Mango & 0,733 & Very Good \\
Others & 0,701 & Very Good \\
Solo_Exp & 0,761 & Very Good \\
Grape & 0,816 & Excellent \\
Veg_Nat & 0,953 & Excellent \\
\hline 'Class denomination; ${ }^{2 K a p p a i n d e x ; ~}$ Mapping quality &
\end{tabular}

In a general manner the value of 0,778 was observed for the mapping quality, classified as "very good" according to Amaral et al. (2009). The mapping quality of the areas occupied by the classes "Water", "Area_Urb", "Coconut", "Grape" and "Veg_Nat" was classified as Excellent, observing the variation in the Kappa statistic varying from 0,809 to 0,953 . As to the mapping quality of the areas occupied by "Banana", "Mango", "Others" and "Soil_Exp", it was considered Very Good, with a variation from 0,701 to 0,761 for the statistic. And for the classes "Acerola" and "Guava" the mapping was attributed to the "Good" condition.

Nery et al. (2013) performed the supervised classification of the Resourcesat-1 (sensor LISS3) satellite images, and by evaluating the Maxver, Maxver-ICM and Minimal Euclidian Distance methods, they observed that the
Kappa statistics presented the values of $0,74,0,75$ e 0,61, respectively. Bolfe et at. (2004), evaluating the precision of the digital classification obtained in the survey of implanted and natural forest occupations in the chart area of Cachoeira do Sul-RS found the value of 0,849 for the Kappa index. Valente \& Vettorazzi (2003), aiming to present the usage and soil covering map of the hydrographic basin of the Corumbataí river, through a supervised classification of the spot and Landsat 5 satellite images, observed that the Kappa statistic varied from 0,75 to 1 for the mapping which identified the features of sugarcane, pasture, planted forest, native forest, fruticulture e annual crop. Fonseca et al. (2016), performing the mapping of the use and covering of the soil in the municipalities of Janaúba e Nova Porteirinha, Minas Gerais state, observed, for the supervised classification with the Maxver, the 
Kappa coefficient of 0,995. Tisot et al. (2007), with the purpose of classifying agricultural targets with both well-defined and subtle spectral differences respectively observed Kappa indexes equivalent to 0,85 and 0,58 for the mappings generated utilizing the $\mathrm{ETM}^{+}$sensor together with the Maxver classifier.

The areas of use and soil covering classes, obtained through supervised classification were measured and are presented in Table 4, for the C1, C2, N1, N2, N3, N4 and N5 producer nuclei of the study territory belonging to the PINC.

Table 4. Measuring of the usage and soil covering areas for the mapping classes obtained through supervised classification for the study territory belonging to the PINC.

\begin{tabular}{cccccccccc}
\hline $\begin{array}{c}\text { Classes/ } \\
\text { Nuclei }\end{array}$ & $\begin{array}{c}\mathrm{Cl} \\
\text { (ha) }\end{array}$ & $\begin{array}{c}\mathrm{C} 2 \\
\text { (ha) }\end{array}$ & $\begin{array}{c}\mathrm{N} 1 \\
\text { (ha) }\end{array}$ & $\begin{array}{c}\mathrm{N} 2 \\
\text { (ha) }\end{array}$ & $\begin{array}{c}\mathrm{N} 3 \\
\text { (ha) }\end{array}$ & $\begin{array}{c}\mathrm{N4} \\
\text { (ha) }\end{array}$ & $\begin{array}{c}\mathrm{N} 5 \\
\text { (ha) }\end{array}$ & $\begin{array}{c}\text { Total } \\
\text { (ha) }\end{array}$ & $\begin{array}{c}\text { Total } \\
\text { (\%) }\end{array}$ \\
\hline Acerola & 13,93 & 62,71 & 101,81 & 88,29 & 109,99 & 198,74 & 110,45 & 685,92 & 3,75 \\
Water & 0,95 & 5,76 & 18,35 & 34,17 & 10,93 & 39,13 & 31,14 & 140,43 & 0,77 \\
Area_Urb & 83,23 & 116,97 & 330,17 & 417,64 & 289,41 & 475,38 & 318,09 & $2.030,89$ & 11,10 \\
Banana & 11,06 & 30,53 & 76,6 & 70,72 & 68,09 & 101,42 & 61,31 & 419,73 & 2,29 \\
Coconut & 13,67 & 50,62 & 86,26 & 103,16 & 159,78 & 557,56 & 152,43 & $1.123,48$ & 6,14 \\
Guava & 33,5 & 114,79 & 205,87 & 188,6 & 165,03 & 275,93 & 144,15 & $1.127,87$ & 6,16 \\
Mango & 47,42 & 158,75 & 242,51 & 262,48 & 182,11 & 359,73 & 243,74 & $1.496,74$ & 8,18 \\
Others & 104,54 & 400,36 & 706,27 & 590,62 & 481,18 & 883,5 & 499,04 & $3.665,51$ & 20,03 \\
Solo_Exp & 122,29 & 117,96 & 383,2 & 346,33 & 319,97 & 667,4 & 467,23 & $2.424,38$ & 13,25 \\
Grape & 26,15 & 101,55 & 191,66 & 97,9 & 147,12 & 244,97 & 180,12 & 989,47 & 5,41 \\
Veg_Nat & 236,06 & 82,11 & 874,79 & 690,52 & 722,9 & $1.143,85$ & 448,91 & $4.199,14$ & 22,94 \\
Total & 692,8 & $1.242,11$ & $3.217,49$ & $2.890,43$ & $2.656,51$ & $4.947,61$ & $2.656,61$ & $18.303,56$ & 100,00 \\
\hline
\end{tabular}

With the presented results it is possible to verify that, currently, the classes constituted by fruit species of greater economical expression cultivated in the study area represented $31,93 \%$ of the cover, which corresponded to an area of 5.843,21 ha. The positioning, concerning the magnitude of soil covering for these fruit species was firstly occupied by mango, followed by the guava, coconut, grape, acerola and banana crops.

For the class "Others" an occupation of $20,03 \%$ was observed, which corresponded to expressive $3.665,51$ ha of cover. Specifically, the class "Others" was constituted by the areas occupied by passion fruit, melon, watermelon, corn, onion, pumpkin, sweet potato, tomato, bell pepper, among others of little economical and occupational expression. Yet, for the referred classes, the occurrence of pastures containing buffel and elephant grasses was confirmed, intercropping or not.

The class of urban areas "Area_Urb" is associated to areas occupied by the Petrolina airport and by the edifications of the agro villages of the C1, N1, N2 and N4 nuclei, as well as by the road mesh of the Irrigation Perimeter Nilo Coelho. As to the areas inserted in the exposed soil class Soil_Exp", they resemble areas which were in process of conventional soil preparation, or even areas of mineral deposit, or areas with implantation or eradication processes of grape and/or passion fruit orchards, with few areas in abandon situation in these nuclei inserted in the study area.

\section{Conclusions}

Based on the observed results it was possible to reach the following conclusions:

The unsupervised classification model (Isodata algorithm) was of great utility for the definition of the classes which presented different spectral answers, with its application distinguishing the classes of irrigated agricultural crops, natural vegetation, exposes soil and urban area (edified);

The supervised classification model (Maxver algorithm) presented elevated sensibility in distinguishing the spectral answers patterns for the subclasses of irrigated agricultural crops, being possible the identification of the soil usages which corresponded to the mango, guava, coconut, grape, acerola and banana crops, among other crops;

The mapping result of the supervised classification was categorized as "very good". 
For the study region, constituted by the C1, C2, N1, N2, N3, N4 and N5 nuclei, it was observed, in average, that the mango, guava and coconut crops were presented as the most expressive in quantitative terms of irrigated areas; and

In the study region there is an expressive covering occupied with passion fruit, melon, watermelon, bean, onion, pumpkin, sweet potato, tomato and bell pepper crops, among others, aside from pasture areas and agricultural intercrops, for which the Maxver algorithm did not present enough sensibility for separately distinguishing them.

\section{References}

Andrade, A.C., Francisco, C.N., Almeida, C.M. 2014. Desempenho de classificadores paramétrico e não paramétrico na classificação da fisionomia vegetal. Revista Brasileira de Cartografia 66: 349-363.

Amaral, M.V.F., Souza, A.L., Soares, V.P., Soares, C.P.B., Leite, H.G., Martins, S.V., Fernandes Filho, E.I., Lana, J.M. 2009. Avaliação e comparação de métodos de classificação de imagens de satélites para o mapeamento de estádios de sucessão florestal. Revista Árvore 33: 575-582.

Antunes, J.F.G., Mercante, E., Esquerdo, J.C.D.M., Lamparelli, R.A.C., Rocha, J.V. 2012. Estimativa de área de soja por classificação de imagens normalizada pela matriz de erros. Pesquisa Agropecuária Brasileira 47: 1288-1294.

Araújo, G.J.F., Silva, M.M. 2013. Crescimento econômico no semiárido brasileiro: o caso do polo frutícola Petrolina/Juazeiro. Caminho de Geografia 14: 246-264.

Bolfe, E.L.; Pereira, R.S.; Madruga, P.R.A.; Fonseca, E.L. 2004. Avaliação da classificação digital de povoamentos florestais em imagens de satélite através de índices de acurácia. Revista Árvore 28: 85-90.

Borges, E.F.; Silva, A.B. 2009. Técnicas de segmentação de imagens e classificação por região: mapeamento da cobertura vegetal e uso do solo, Mucugê-BA. Mercator 8: 209-220.

FAO 2014. Statistical Yearbook: Latin America and the Caribbean Food and Agriculture. Food and Agriculture Organization of the United Nations (FAO): Regional Office for Latin America and the Caribbean, Santiago, Chile. 180p.

Fernandes, R.R., Nunes, G.M., Silva, T.S.F. 2012. Classificação orientada a objetos aplicada na caracterização da cobertura da terra no
Araguaia. Pesquisa Agropecuária Brasileira 47: 1251-1260.

Ferreira, M.V.; Riedel, P.S.; Marques, M.L.; Tinos, P.M. 2010. Comparação entre técnicas de classificação digital de imagens para detecção de mudanças do uso e cobertura da terra. Revista Brasileira de Cartografia 62: 613-627.

Fonseca, S.F., Hermano, V.M., Silva, A.C. 2016. Mapeamento do uso da terra nos municípios de Janaúba e Nova Porteirinha (MG) usando dados de sensoriamento remoto. Élisée, Revista de Geografia da UEG 5: 103-119.

Leite, M.E., Santos, I.S., Almeida, J.W.L. 2011. Mudança de uso do solo na bacia do rio Vieira, em Montes Claros/MG. Revista Brasileira de Geografia Física 04: 779-792.

Leite, E.F., Rosa, R. 2012. Análise do uso, ocupação e cobertura da terra da bacia hidrográfica do Rio Formiga, Tocantins. Revista Eletrônica de Geografia 04: 90-106.

Marinho, R.R., Paradella, W.R., Rennó, C.D., Oliveira, C.G. 2012. Aplicação de imagens SAR orbitais em desastres naturais: mapeamento das inundações de 2008 no Vale do Itajaí, SC. Revista Brasileira de Cartografia 64: 317-330.

Mello, A.Y.I., Alves, D.S.A., Linhares, C.A., Lima, F.B. 2012. Avaliação de técnicas de classificação digital de imagens Landsat em diferentes padrões de cobertura da Terra em Rondônia. Revista Árvore 36: 537-547.

Melo Júnior, J.C.F., Costa, D.S., Gervásio, E.S., Nascimento, A.M., Sediyama, G.C. 2015. Efeito de níveis de depleção de água no substrato e doses de fertilizante de liberação controlada na produção de mudas de maracujazeiro amarelo. Irriga 20: 204-219.

Melo Júnior, J.C.F., Lima, A.M., Teixeira, M.V., Conceição, G.C., Santos, L.R. 2014. Depleção de água no substrato e doses de fertilizante Osmocote na formação de mudas de mamoeiro. Comunicata Scientiae 5: 499-508.

Moreira, M.A. 2011. Fundamentos do sensoriamento remoto e metodologias de aplicação. Editora UFV, Viçosa, Brasil. 422 p.

NASA. Frequently Asked Questions about the Landsat Missions. 2013. http://landsat.usgs.gov/ contactus.php<Acesso em 15 Out. 2014>

Nery, G.V.M., Fernandes, F.H.S., Moreira, A.A., Braga, F.L. 2013. Avaliação das técnicas de classificação Maxver, Maxver-ICM e Distância Mínima Euclidiana de acordo com o índice Kappa. Revista Brasileira de Geografia Física 06: 320-328. 
Prishchepov, A.V., Radeloff, V.C., Dubinin, M., Alcantara, C. 2012. The effect of Landsat ETM/ ETM+ image acquisition dates on the detection of agricultural land abandonment in Eastern Europe. Remote Sensing of Environment 126: 195209.

Rodrigues, M.T., Pollo, R.A., Rodrigues, B.T., Malheiros, J.M., Campos, S. 2014. Sensoriamento remoto e geoprocessamento aplicado ao uso da terra para avaliação entre classificadores a partir do índice Kappa. Revista Científica Eletrônica de Engenharia Florestal 23: 60-70.

Silva, A.F., Barbosa, A.P., Zimback, C.R.L., Landim, P.M.B. 2013. Geostatistics and remote sensing methods in the classification of images of areas cultivated with citrus. Engenharia Agrícola 33: 1245-1256.

Silva Júnior, C.A., Bacani, V.M., Carvalho, L.A. 2013. Rotinas de tratamento digital de imagem Landsat 5/TM para a identificação de queimadas em lavouras canavieiras. Bioscience Journal 29: 1514-1523.

Tisot, D.A., Formaggio, A.R., Rennó, C.D., Galvão, L.S. 2007. Eficácia de dados Hyperion/EO-1 para identificação de alvos agrícolas: comparação com dados ETM+/Landsat-7. Engenharia Agrícola 27: 511-519.

Valente, R.O.A., Vettorazzi, C.A. 2003. Mapeamento do uso e cobertura do solo da Bacia do Rio Corumbataí, SP. Circular Técnica n.196. Instituto de Pesquisa e Estudos Florestais, Piracicaba, Brasil. 10p.

Wrublack, S.C., Mercante, E., Boas, M.A.V. 2013. Mapping of use and occupation of the soil and irrigation water quality in the city of Salto do Lontra-Paraná, Brazil. Engenharia Agrícola 34:1024-1037. 